\title{
Appendix \\ The Formation of the Talmud according to Halevy
}

\section{Amoraic Era}

\begin{tabular}{lll}
\hline ca. 308 & $\begin{array}{l}\text { Abbaye and Rava and the compilation of the proto- } \\
\text { Talmud }\end{array}$ & Pumbedita \\
\hline 324 & Inclusion of the traditions of the Palestinian sages & Pumbedita \\
\hline $351 / 2$ & $\begin{array}{l}\text { Death of Rava and the end of the compilation of the } \\
\text { proto-Talmud }\end{array}$ & $\begin{array}{l}\text { Sura and } \\
\text { Pumbedita }\end{array}$ \\
\hline ca. $391 / 2$ & $\begin{array}{l}\text { Final redaction and editing of the Talmud by Rav } \\
\text { Ashi's court }\end{array}$ & Matta Mehasia ${ }^{1}$ \\
\hline $422 / 6 ?$ & Rav Ashi's death and the post-Rav-Ashi editing & Matta Mehasia \\
& & and Sura \\
\hline $474 / 5$ & $\begin{array}{l}\text { Death of Ravina bar Huna and the closing of the } \\
\text { Talmud }\end{array}$ & Sura \\
\hline
\end{tabular}

\section{Saboraic Era}

\begin{tabular}{lll}
\hline 474/5 & $\begin{array}{l}\text { Rav Yose and the first generation of Saboraim } \\
\text { (Rabbanan Demefarshei) } \\
\text { Committing of the Talmud to writing }\end{array}$ & Pumbedita \\
\hline ca. $510 / 20$ & Reopening of Sura, with Rav Eina named its head & Sura \\
\hline ca. 520 & Death of Rav Yose and end of the Rabbanan Demefarshei & Pumbedita \\
\hline 520 & $\begin{array}{l}\text { Later Saboraim and minor editing of/cosmetic work on the } \\
\text { Talmud } \\
\text { Rav Eina } \\
\text { Rav Simona }\end{array}$ & $\begin{array}{l}\text { Sura } \\
\text { Pumbedita }\end{array}$ \\
\hline
\end{tabular}

1 Brody says that Matta Mehasia was the geonic name for Sura, but Halevy claimed to prove from the Talmud that Sura and Matta Mehasia were two adjacent cities. See Brody, The Geonim of Babylonia, 36; and Halevy, Dorot harishonim, 2:593-600. 


\begin{tabular}{lll}
\hline ca. 540 & $\begin{array}{l}\text { Rav Eina's death and the closing of Sura due to new } \\
\text { persecutions }\end{array}$ & \\
\hline 560 & $\begin{array}{l}\text { Death of Rav Revai of Rov and temporary closure of } \\
\text { Pumbedita }\end{array}$ & \\
\hline 570 & Creation of a new beit hava'ad & Piruz Shabur ${ }^{2}$ \\
\hline & Composition of Masekhtot qetanot & Nehardea \\
\hline
\end{tabular}

\section{Geonic Era}

\begin{tabular}{lll}
\hline 589 & Appointment of first Gaon and end of saboraic era & Pumbedita \\
\hline 609 & Reopening of the academy in Sura & Sura \\
\hline 689 & Sura firmly established and title Gaon firmly used & Sura \\
\hline
\end{tabular}

2 In the surroundings of Nehardea (Lewin, ed., Iggeret Rav Sherira Gaon, 99). 